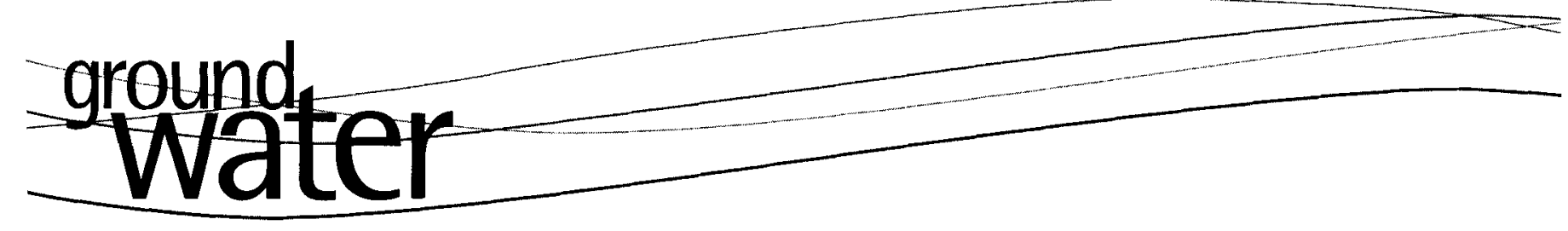

\title{
Regional Estimation of Total Recharge to Ground Water in Nebraska
}

by Jozsef Szilagyi ${ }^{1,2}$, F. Edwin Harvey', and Jerry F. Ayers'

\begin{abstract}
Naturally occurring long-term mean annual recharge to ground water in Nebraska was estimated by a novel water-balance approach. This approach uses geographic information systems (GIS) layers of land cover, elevation of land and ground water surfaces, base recharge, and the recharge potential in combination with monthly climatic data. Long-term mean recharge $>140 \mathrm{~mm}$ per year was estimated in eastern Nebraska, having the highest annual precipitation rates within the state, along the Elkhorn, Platte, Missouri, and Big Nemaha River valleys where ground water is very close to the surface. Similarly high recharge values were obtained for the Sand Hills sections of the North and Middle Loup, as well as Cedar River and Beaver Creek valleys due to high infiltration rates of the sandy soil in the area. The westernmost and southwesternmost parts of the state were estimated to typically receive $<30 \mathrm{~mm}$ of recharge a year.
\end{abstract}

\section{Introduction}

In regional-scale water balance and ground water modeling studies, recharge to the ground water is an important but often poorly known variable because it is influenced by a host of meteorological, environmental and biological factors with potentially significant spatial variability. The large number of existing recharge estimation techniques highlights its importance in water resource assessment, contaminant transport, and aquifer vulnerability studies. Scanlon et al. (2002) provides an excellent account of the various techniques available to date.

Often recharge is assumed to be equal to the ground water contribution (i.e., base flow) to the stream within a watershed (Rutledge and Daniel 1994; Mau and Winter 1997) over long periods of time when the potential change in ground water storage becomes negligible compared to the cumulative ground water discharge volume. Szilagyi et al. (2003) labeled this recharge "base recharge." Base recharge, defined in this manner, is the total recharge reduced by the amount of any potential losses from ground

\footnotetext{
Associate professor, Conservation and Survey Division, School of Natural Resources, Lincoln, NE 68588-0517; (402) 472-9667; fax: (402) 472-4608

${ }^{2}$ Corresponding author: jszilagyi1@unl.edu

Received August 2003, accepted April 2004.

Copyright $(2005$ by the National Ground Water Association.
}

water storage other than discharge to streams. One such loss term is evapotranspiration (ET) from ground water, typically by phreatophytes along river valleys (Rantz 1968; Nagel and Dart 1980; Culler et al. 1982) or in wetland areas where the ground water is close to the surface. In semiarid to arid regions where phreatophyte vegetation may be widespread along ephemeral or perennial river valleys, and where precipitation and areal evaporation are diminished, ground water ET may become an important part of the water balance (through its increased relative weight), and consequently in such catchments, base and total recharge may differ significantly.

Base recharge is relatively simple to estimate using the approach of Szilagyi et al. (2003). An extension of their technique for identifying areas where ground water ET is likely to occur is demonstrated for Nebraska. The WREVAP model of Morton et al. (1985), an extensively tested (Hobbins et al. 2001) areal ET calculation algorithm, provides an estimate for the expected magnitude of this additional ground water ET. Spatially distributed base recharge is augmented to account for this extra source of ground water consumption through water balance considerations and the use of a recharge-potential map (Conservation and Survey Division [CSD] 1996). A schematic diagram (Figure 1) shows that recharge is balanced by two processes (provided communication of water between the unconfined and confined aquifers is negligible or absent): base flow and ground water ET, the latter mainly through the water 


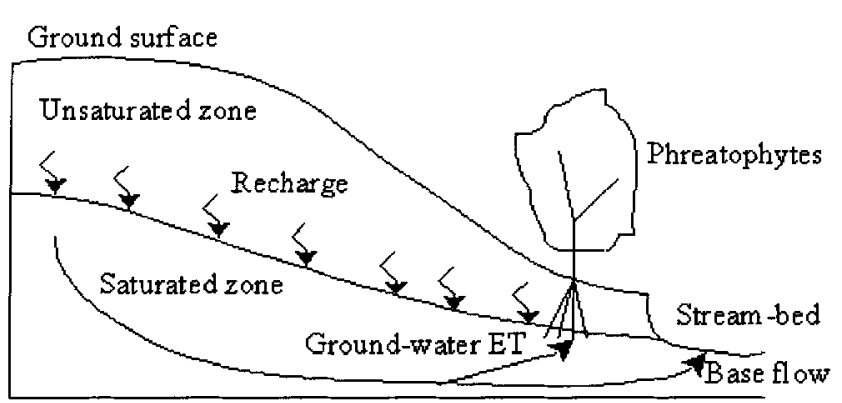

Figure 1. Schematic representation of the sources and sinks of ground water considered in the study.

use (i.e., transpiration) of phreatophyte vegetation alongside the stream channels.

\section{Methodology}

Through the application of a simple water-balance equation and the use of an automated base flow separation algorithm (Nathan and McMahon 1990; Szilagyi et al. 2003), one can produce regional-scale maps of estimated base recharge, as was demonstrated by Szilagyi et al. (2003). In humid environments, base recharge may be a good estimator of total recharge to the ground water. More arid regions, such as Nebraska, where the mean runoff ratio (Figure 2) is only $10 \%$ to $11 \%$ (Szilagyi et al. 2003), are often characterized by wide alluvial valleys lushly covered with phreatophytes (predominantly willow and cottonwood [Nagel and Dart 1980]). The several kilometers wide Platte River valley is a perfect example (Figure 3 ), where ground water ET may play an important role in the water balance of the unconfined aquifer (Nagel and Dart 1980) and thus in regional recharge estimations.

Nagel and Dart (1980) demonstrated for the Platte River valley that areas with phreatophyte vegetation transpire as much water as open water surfaces evaporate. Their finding is not at all surprising for the practicing hydrologist (Brutsaert 1982). Since small open water surfaces evaporate at the potential level, phreatophyte ET can be assumed to be virtually equal to the potential evapotranspiration (PET) in the area (Figure 4). The latter is supplied by the WREVAP model (Morton et al. 1985) utilizing cli-

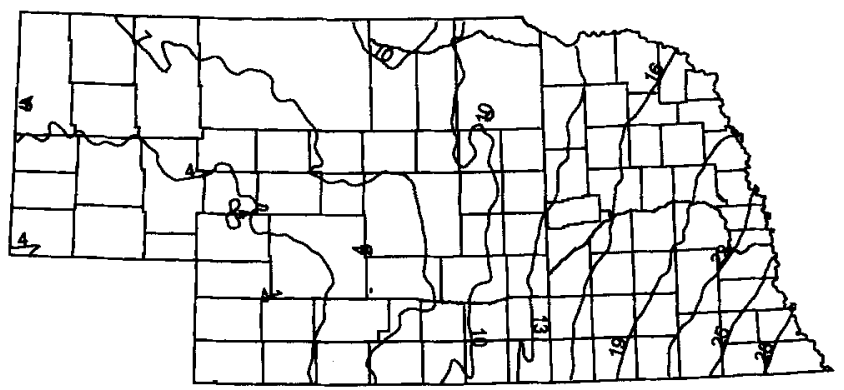

100
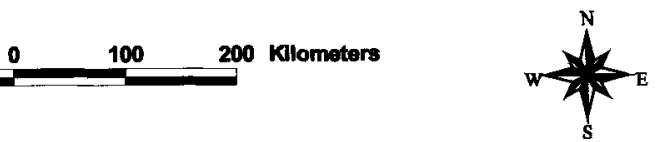

Figure 2. Mean annual runoff ratio (\%) for Nebraska.

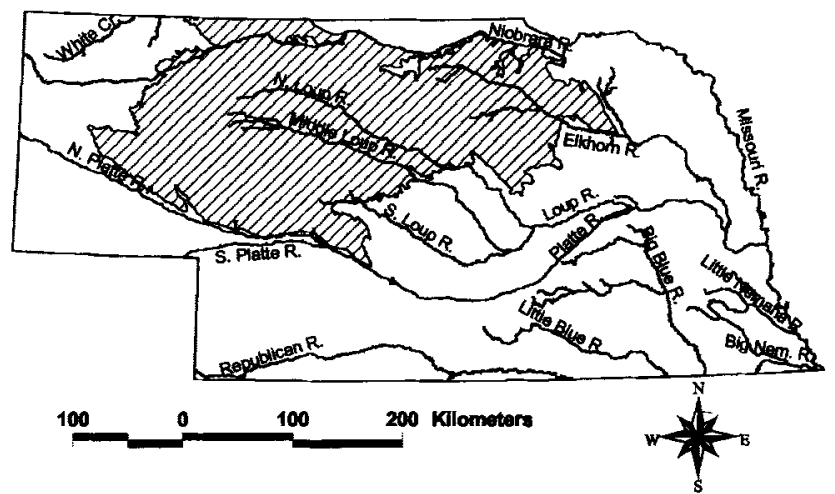

Figure 3. Geographic location of the Sand Hills and major rivers in Nebraska.

matic data (Szilagyi et al. 2003) from the Solar and Meteorological Surface Observation Network (SAMSON) stations. Areas with possible phreatophyte vegetation in Nebraska were identified using the following criteria. (1) The ground water surface (CSD 2001) must be within $2 \mathrm{~m}$ of the land surface. (2) The land cover class of the 1:250,000-scale land use/land cover (LU/LC) GIS map (USGS 1990) is of either of the following categories: deciduous or mixed forest, and forested or nonforested wetland. (Note that the smallest possible area of any land class in the LU/LC map is $0.04 \mathrm{~km}^{2}$ with a minimum width of $200 \mathrm{~m}$.) A depth to the water table of $<2 \mathrm{~m}$ means that vegetation can have easy access to abundant soil moisture. This occurs either directly from the ground water, as in the case of phreatophytes (Miller 1977), or from the capillary fringe in the root zone that can reach $>2 \mathrm{~m}$ for broad-leafed trees and tall herbaceous vegetation (Eagleson 1970).

Figure 5 displays the areas assumed to be covered by phreatophyte vegetation. In these areas ground water ET (Figure 5), which is considered as mainly phreatophyte transpiration from the ground water, was taken as the difference between mean annual PET and ET (Figure 6); the latter was also provided by the WREVAP model. However, this does not mean that phreatophytes would not use water also from the vadose zone, in addition to transpiration directly from the ground water. Note that practically everywhere in Nebraska transpiration rates by phreatophytes using ground water alone can be larger than ET rates of the

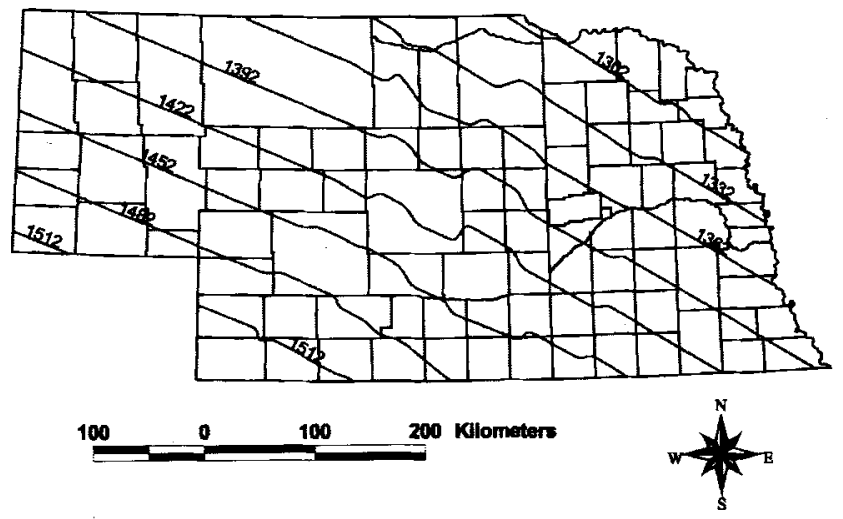

Figure 4. Mean annual PET (mm) for Nebraska. 


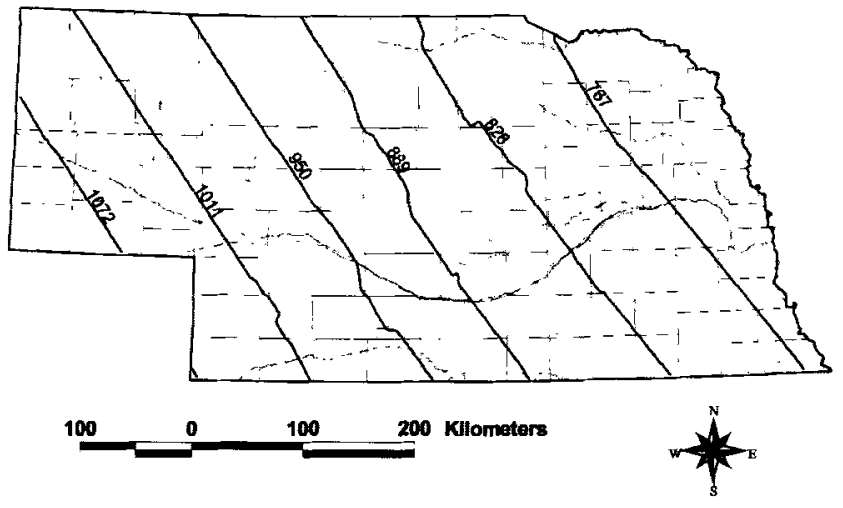

Figure 5. Areas with assumed phreatophyte cover. The contour lines indicate mean annual values $(\mathrm{mm})$ of estimated ground water ET of phreatophytes.

surrounding area. It may be important to point out here that the WREVAP-calculated ET value at a point represents the evapotranspiration of extended areas (Morton et al. 1985) several hundreds of square kilometers in size. This way the elevated ET values of the phreatophyte vegetation confined to relatively small areas are already incorporated in the WREVAP model's ET values (Figure 6) in a spatially smoothed way. This ensures the correctness of the modeled runoff ratios (Figure 2).

The ground water used by phreatophytes must be supplied by increased recharge rates if the ground water is to be kept in equilibrium (Figure 1), which is the case for Nebraska with the exception of certain areas affected by human activity in the form of intensive irrigation systems or leaking irrigation canals (CSD 1998). Accounting for these localized anthropogenic effects with a transient local water table is beyond the scope of this study. Nor will this study attempt to assess ground water use by irrigated crops in other areas where no ground water decline was reported. Estimating losses from the ground water through irrigation is complicated by the varying degrees of efficiency in irrigation techniques; by the source of the irrigation water, whether from surface or ground water; by crop type and cultivation characteristics (such as row and plant distance, etc.); by planting and harvesting times; and by the typically unknown amount of irrigation water that percolates back to the ground water or runs off to nearby streams.

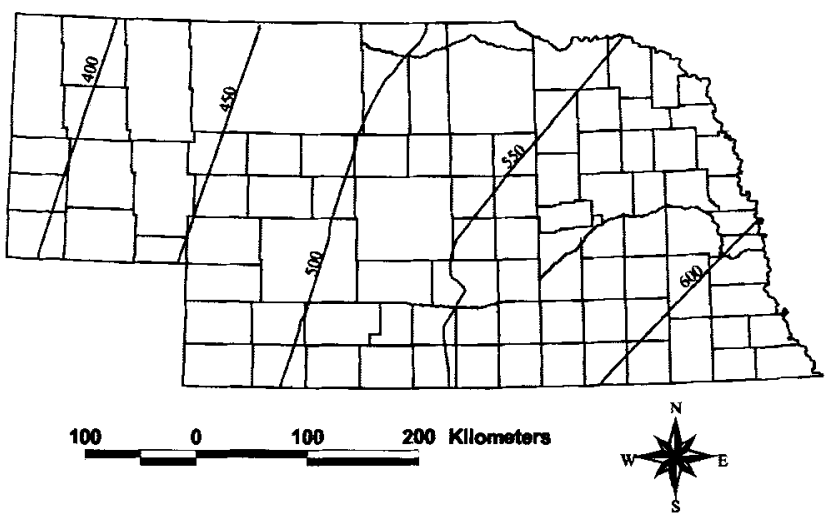

Figure 6. Mean annual ET (mm) for Nebraska (from Szilagyi et al. 2003).
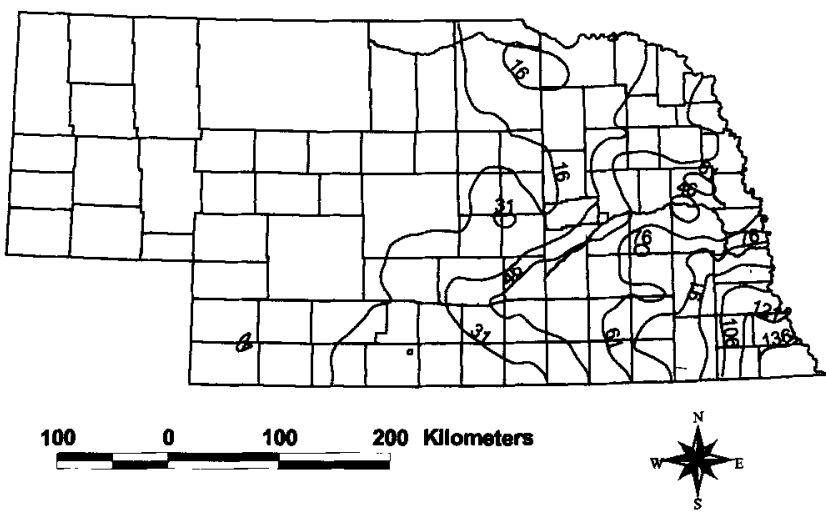

Figure 7. Mean annual surface runoff $(\mathrm{mm})$ for Nebraska.

In equating recharge increases on top of base recharge to ground water ET (Figure 1), we assume that the phreatophyte water uptake does not entail induced recharge to the ground water from the streams. This assumption may not be true generally, but it works to our advantage, not only by simplifying our task of estimating long-term total recharge but also by supplementing for at least some of the increased but unknown recharge required to balance out ground water losses by large-scale irrigation. Note that due to the presence of induced recharge (although of unknown extent), one overestimates additional recharge on top of base recharge when taking it equal to the PET minus ET value of phreatophyte areas, since an unknown part of this difference is supplied by water from the stream and not by increased recharge rates of the region. At the same time, large-scale irrigation using water from the ground results in a net loss of ground water which must be balanced out by increased rates of recharge, if the region's ground water is to be kept in a long-term equilibrium. The two effects may cancel each other out, in terms of the recharge estimates; however, it may be hard to prove.

When augmenting base recharge $\left(R_{b}\right)$ to estimate total recharge $(R)$, the following equation was used:

$$
R=c_{1}\left(P-Q_{s}\right)=R_{b}+c_{2}\left(P-Q_{s}\right)
$$

where $P$ is mean annual precipitation, $Q_{s}$ is mean annual surface runoff, and $c_{l}$ and $c_{2}$ are empirical positive constants to be optimized. $Q_{s}$ (Figure 7) can be obtained as total runoff minus base flow. (Note that surfaces of the climatic and hydrologic variables were generated by kriging [Szilagyi et al. 2003].) The $P-Q_{s}$ term is the theoretical upper limit for recharge at any given location. Of course, recharge is always smaller than $P-Q_{s}$ because some water is stored in the vadose zone from which it may escape back to the atmosphere either as direct soil evaporation or via transpiration of the vegetation. The application of the righthand side of Equation 1 and the subsequent optimization of $c_{2}$ ensures that the estimated total recharge rate will always be larger than the corresponding rate of base recharge. The optimization of $c_{2}$ was assisted by use of a digital recharge potential map (CSD 1996) that classifies land areas (using the DRASTIC method [Aller et al. 1987]) into eight different categories by assigning integer numbers $(n)$ from 0 to 7 (Figure 8), where the highest number designates the most 


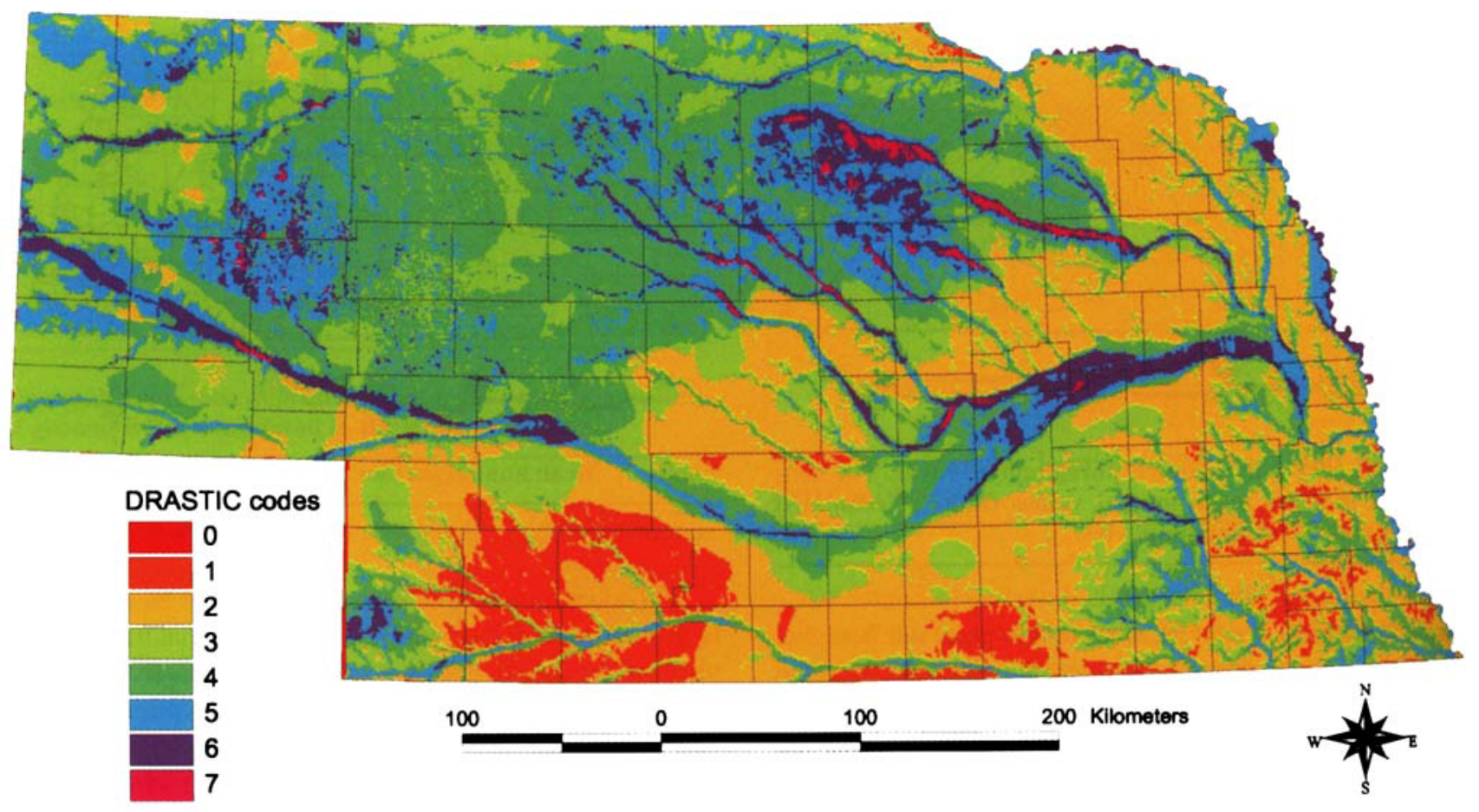

Figure 8. DRASTIC code values for Nebraska. A large value means high recharge potential.

favorable conditions for recharge. The categories are based on evaluating surface, vadose zone, and aquifer properties (Rundquist et al. 1991). The value of $c_{2}$ was set equal to zero for $n=0$ and 1 , and, progressing from the most favorable category to the least one, each subsequent $c_{2}$ value was set to half of the preceding one. This way only one value had to be determined, i.e., the largest $c_{2}$ value for $n=7$. Applying an exponential (and not, for example, a linear) distribution of the $c_{2}$ values among the categories may seem somewhat arbitrary. However, a classification serves its purpose if the chosen property, in our case estimated recharge, changes notably with the categories. A doubling (or equally halving) of any continuous quantity is a natural choice for a notable change between the categories. Note that some degree of arbitrariness is already inherent in the DRASTIC method used for the recharge potential map because of the way varying weights are assigned to aquifer, surface, and vadose zone properties (Rundquist et al. 1991). Nonetheless, the optimization conserved mass, assuring that the long-term ground water volume used by phreatophytes equals the difference between long-term mean total recharge and base-recharge volumes when averaged over the state as it should if no sink (besides base flow) other than phreatophyte transpiration exists for the recharged water (Figure 1). The difference between WREVAP-calculated phreatophyte transpiration using ground water and the term $R-R_{b}$ served as the objective function to be minimized in the absolute sense (i.e., the minimum is zero).

The Sand Hills region is dotted with more than a thousand shallow lakes of varying size (Figure 9). The exact number is hard to tell because it changes within wet and dry years (Bleed and Flowerday 1989). These lakes are typically ground water-fed (Bleed and Flowerday 1989) with virtually no surface water contribution, and thus they act like phreatophytes in terms of ground water consumption through their evaporation. Because of their relatively small average size and shallow depth, this evaporation can be estimated by the corresponding PET rates (Figure 4) in the region. To account for this extra ground water use, Equation 1 was applied a second time for the Sand Hills region, where it was further assumed that the extra loss of ground water is replenished entirely from within the region due to the high infiltration rates of the sandy soils there and the unique topography of the area, where the dunes supply their infiltrated water to the neighboring lakes and fans (Gosselin et al. 1999) that occupy many of the interdunal terrain (Figure 9). Consequently, the repeated application of Equation 1 was constrained to the Sand Hills area only.

\section{Results and Discussion}

The total area of assumed phreatophyte cover (Figure 5) is $1289 \mathrm{~km}^{2}$, which is $0.64 \%$ of the total land area of Nebraska. The mean annual ground water ET rate of these areas is $887 \mathrm{~mm}$, which represents $\sim 6 \mathrm{~mm}$ if it were spread

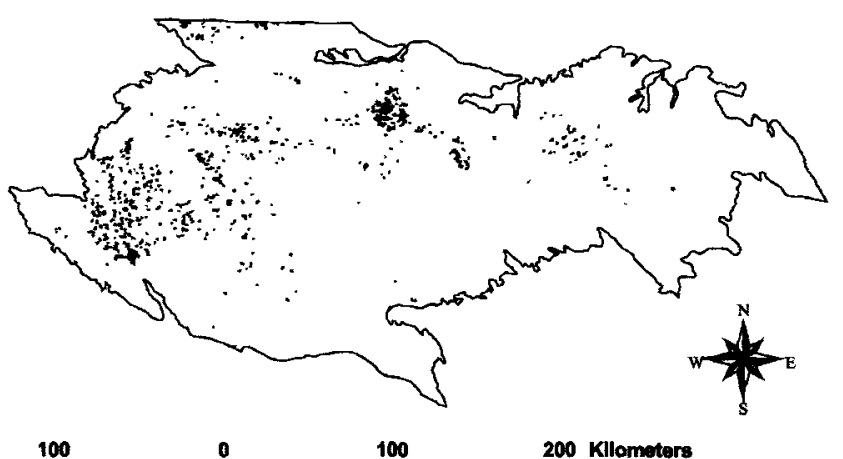

Figure 9. The distribution of the Sand Hills lakes as given by the LU/LC GIS map. 
evenly over the state, accounting for $\sim 1 \%$ of the total ET $(511 \mathrm{~mm})$ of Nebraska. Note that this may seem negligible overall, but it can result in significantly increased values locally. An optimized value of $c_{2}=0.11$ for $n=7$ ensures that this extra ground water sink is matched by increased recharge rates to the saturated zone. In addition to the phreatophytes, the LU/LC map gives a lake cover of 214 $\mathrm{km}^{2}$, which is $\sim 0.43 \%$ of the total area of the Sand Hills region. The Sand Hills lakes evaporate $\sim 1400 \mathrm{~mm}$ ground water per $\mathrm{m}^{2}$ annually, which amounts to an additional 1.5 $\mathrm{mm}$ of ground water use statewide. The application of Equation 1 results in an optimized value of $c_{2}=0.052$ for $n$ $=7$ in the Sand Hills, which ensures that lake evaporation from the ground water is balanced by increased recharge rates in the region.

Figure 10 displays the distribution of additional recharge on top of base-recharge rates reported by Szilagyi et al. (2003). By comparison of Figures 5 and 10, it can be seen that a large part of the area with the highest rates of this additional recharge overlaps with the areas of phreatophyte cover. This is mainly so because in these latter areas the ground water is very close to the surface, i.e., $<2 \mathrm{~m}$ by definition, and so any infiltrating water has a better chance of reaching the saturated zone due to this shorter distance and the smaller total soil volume to be saturated to at least field capacity. Note also the increased recharge values within the Sand Hills region in north-central Nebraska, mostly because of the generally high infiltration rates of the sandy soils there, represented by high $n$ values in Figure 8 . The Sand Hills region has long been regarded as the main recharge area of the large continuous unconfined aquifer (i.e., the Ogallala Formation) underneath the surface of much of Nebraska.

The mean annual total recharge rates are displayed in Figure 11 . The river valleys generally have higher recharge rates than the surrounding areas for reasons previously mentioned. The largest recharge values $(>140 \mathrm{~mm}$ ) can be found in eastern Nebraska, where annual precipitation is the highest (CSD 1998; Szilagyi et al. 2003), along the Elkhorn, Platte, Missouri, and Big Nemaha Rivers (Figure 5). This is in contrast with USGS (2003), where base recharge estimates were greatest in the Sand Hills region, corresponding in magnitude to our total recharge estimates in the area. The pattern largely repeats itself in Figure 12, where recharge is shown as a percentage of precipitation. Note that the Sand Hills region in the north-central part of the state again displays elevated recharge rates when compared to areas south, west, and even east of it. The steepest changes (from 6 to 18 $\mathrm{mm}$ ) in recharge rates can also be found in this region along the Middle and North Loup, as well as along the Cedar River and Beaver Creek (west of the Loups) and also in the extreme western part of the region, where the majority of Sand Hills wetlands are found.

Comparing the total recharge maps of Figures 10 through 12 to maps of estimated long-term base recharge of Szilagyi et al. (2003) and USGS (2003), a change in spatial detail is noticeable. This is because base flow contains information of recharge already integrated over the entire watershed (or more precisely over the drainage area belonging to the specific gauging station), while application of the DRASTIC maps involves recharge potential values based on, among other properties, land use/land cover categories.

\section{Conclusions}

Phreatophyte ET and lake evaporation in the Sand Hills from the ground water increased the estimated longterm mean recharge in Nebraska by $\sim 18 \%$ (48 versus 41 $\mathrm{mm}$ ) when averaged over the state and by $\sim 41 \%$ over the Sand Hills region (Table 1). This is the estimated difference

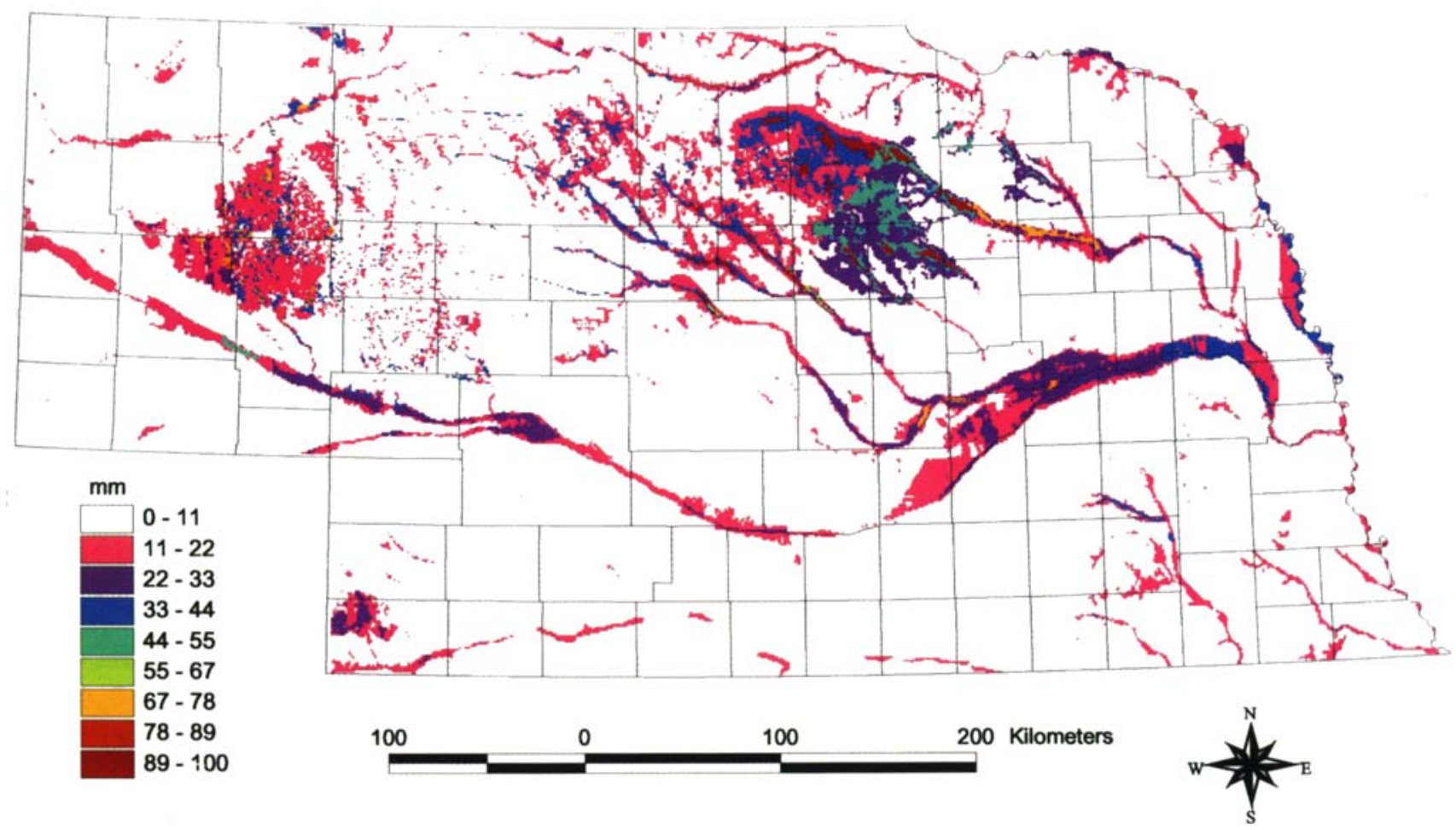

Figure 10. The difference between estimated mean annual total and base recharge $(\mathrm{mm})$ in Nebraska. 


\begin{tabular}{|lcccc|}
\hline \multicolumn{3}{|c|}{$\begin{array}{c}\text { Table 1 } \\
\text { Components of the Recharge Estimates } \\
\text { (Rounded Values) }\end{array}$} & & \\
\hline & $\begin{array}{c}\text { Total } \\
(\mathbf{m m})\end{array}$ & $\begin{array}{c}\text { Percent of } \\
\text { Precipitation }\end{array}$ & $\begin{array}{c}\text { Change to Base } \\
\text { Recharge (mm) }\end{array}$ & $\begin{array}{c}\text { Change to Base } \\
\text { Recharge (\%) }\end{array}$ \\
\hline Nebraska & & & & \\
Base recharge $\left(R_{b}\right)$ & 41 & 7 & - & - \\
Phreatophytes $+\mathrm{R}_{\mathrm{b}}\left(P h R_{b}\right)$ & 46 & 8 & 6 & 14 \\
$P h R_{b}+$ Sand Hills lakes & 48 & 8 & 7 & 18 \\
Sand Hills & & & & - \\
Base recharge $\left(R_{b}\right)$ & 34 & 6 & - & 26 \\
Phreatophytes $+\mathrm{R}_{\mathrm{b}}\left(P h R_{b}\right)$ & 43 & 9 & 14 & 41 \\
$P h R_{b}+$ Sand Hills lakes & 48 & & & \\
\hline
\end{tabular}

between total and base recharge. In reality, one may expect an even larger difference between the two for the following reasons: (1) Our approach could not directly quantify potential ground water losses from widespread irrigation in the state. (2) The spatial resolution of the digital LU/LC map cannot identify phreatophyte and lake areas $<0.04$ $\mathrm{km}^{2}$ or narrow strips of vegetation or lake if the width is $<200 \mathrm{~m}$. (3) Certain crops in the river valleys and wet meadows of the Sand Hills may also use ground water for transpiration when their root system is already developed during the growing season.

It is believed that the approach presented here, combined with previous base-recharge estimations (Szilagyi et al. 2003; USGS 2003), may help regional-scale ground water modelers by providing them with independently obtained mean recharge estimates typically required by their models. It may also help decision makers in the state or interstate panels as they develop future water resource management plans in the High Plains aquifer region. The described water-budget-based technique is novel in its combination of meteorological, hydrological, geological, and vegetation data; easily reproducible; relatively simple; computationally not intensive; and requires generally available GIS coverages. As for its limitations, the technique is most suitable for large areas where water exchange between the unconfined and confined aquifers is minimal and where net influx of water (whether positive or negative) to the area is also negligible.

\section{Acknowledgements}

This work has been supported through the National Science Foundation's grant \#WBS-2564450068001. The authors are grateful to Charles Flowerday for his editorial comments, and to Jeff Raffensperger and two anonymous

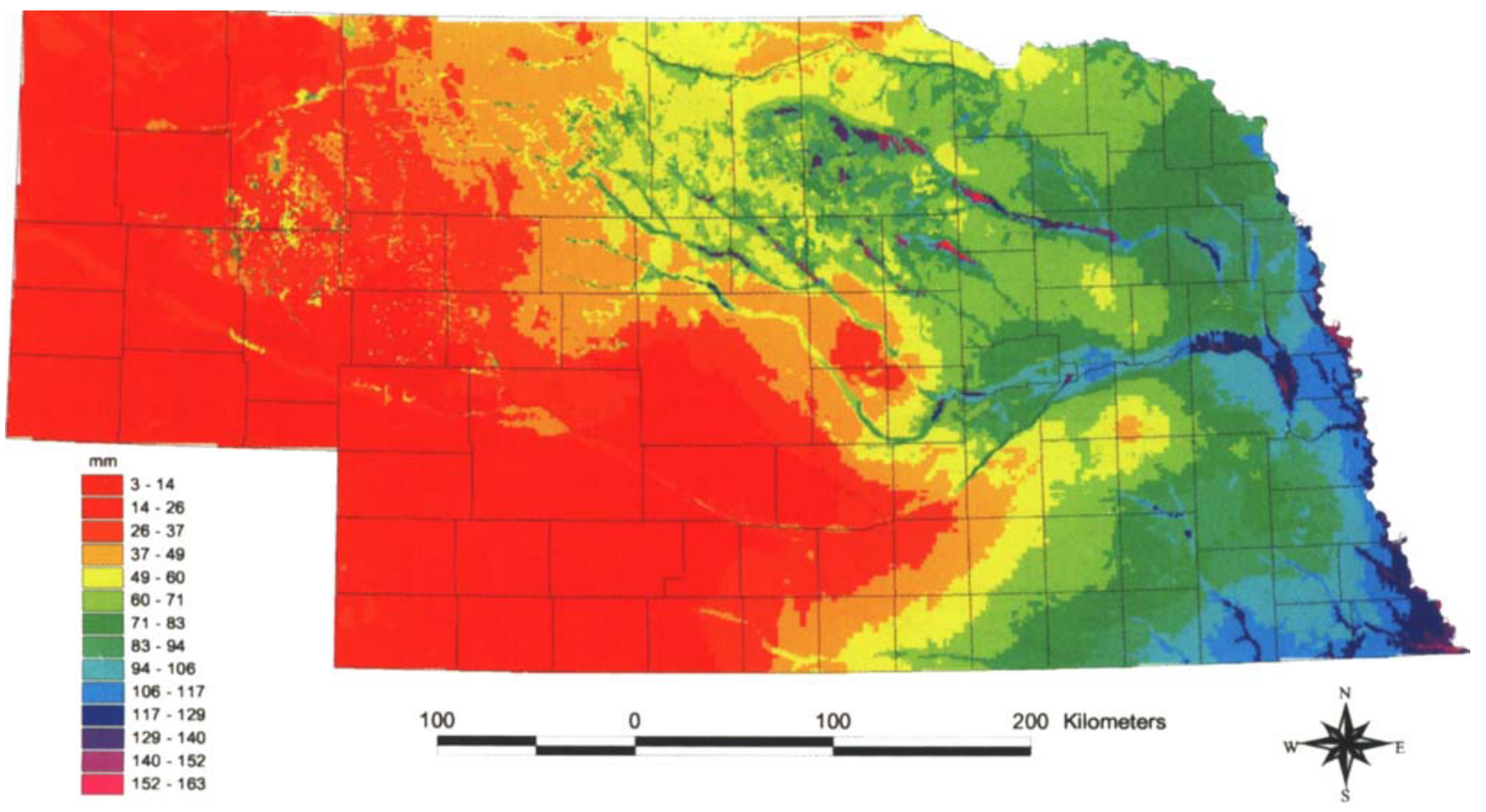

Figure 11. Estimated mean annual total recharge rates (mm) for Nebraska. 


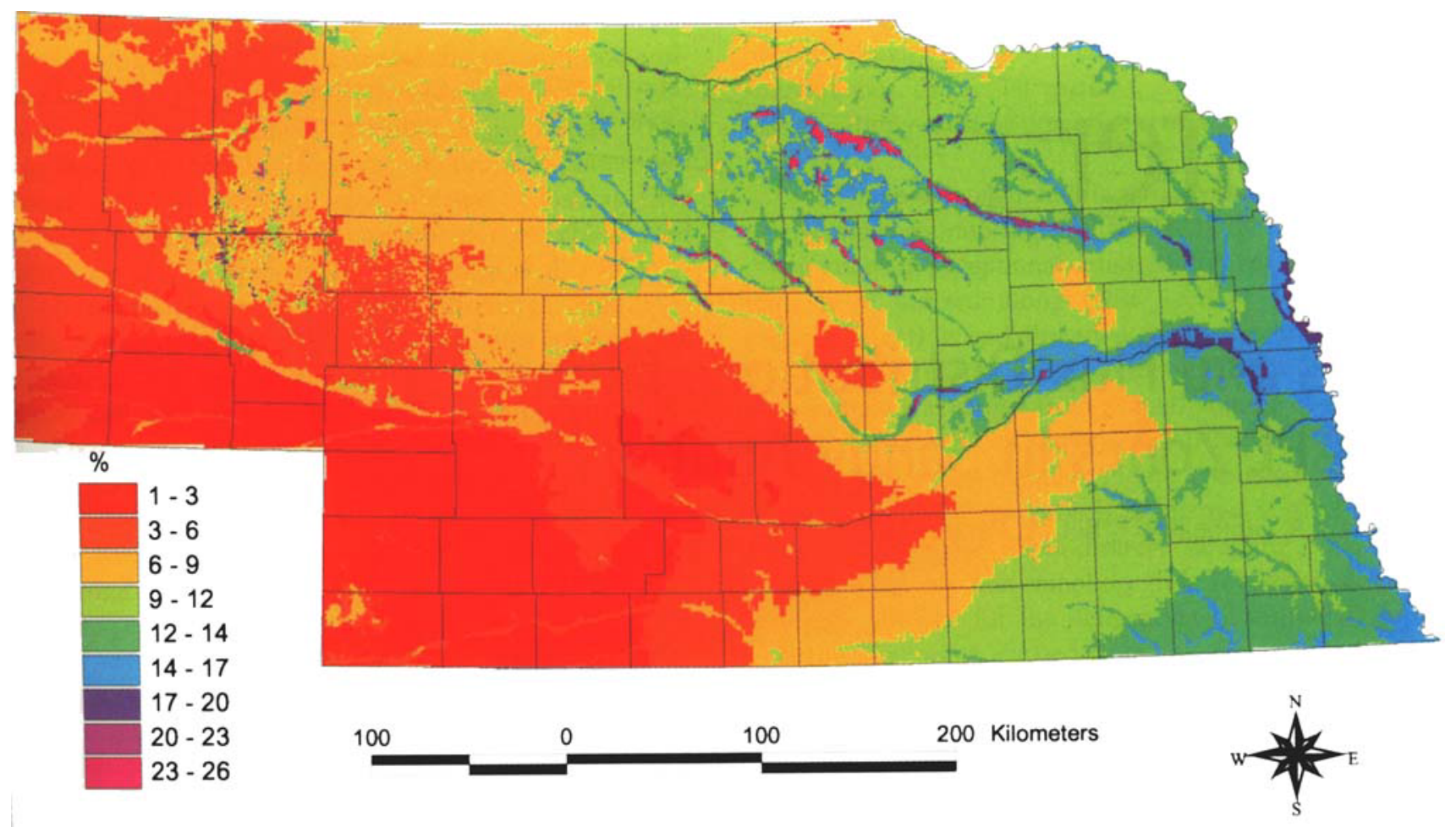

Figure 12. Estimated mean annual total recharge rates as percentage of precipitation in Nebraska.

referees for their valuable comments on an earlier version of the manuscript.

Authors' Note: The views, conclusions, and/or opinions expressed in this paper are solely those of the authors and not the University of Nebraska, the state of Nebraska, or any political subdivision thereof.

\section{References}

Aller, L., T. Bennett, J.H. Lehr, and R.J. Petty. DRASTIC: A standardized system for evaluating groundwater pollution potential using hydrogeologic settings. USEPA Document \#EPA/600/2-85-018.

Bleed, A., and C. Flowerday (eds.). 1989. An Atlas of the Sand Hills. Conservation and Survey Division, University of Nebraska-Lincoln.

Brutsaert, W. 1982. Evaporation into the Atmosphere. Dordrecht, The Netherlands: Kluwer.

Conservation and Survey Division. 1996. Potential for groundwater contamination using the DRASTIC methodology. University of Nebraska-Lincoln, http://csd.unl.edu/csd/ gisdata.html.

Conservation and Survey Division. 1998. The Groundwater Atlas of Nebraska. University of Nebraska-Lincoln.

Conservation and Survey Division. 2001. Configuration of the water table, circa 1995. University of Nebraska-Lincoln, http://csd.unl.edu/csd/misc/gm-54-new.htm.

Culler, R.C., R.L. Hanson, R.M. Myrick, R.M. Turner, and F.P. Kipple. 1982. Evapotranspiration before and after clearing phreatophytes, Gila River flood plain, Graham County, Arizona. Geological Survey Professional Paper 655-P.

Eagleson, P.S. 1970. Dynamic Hydrology. New York: McGrawHill.

Gosselin, D.C., S. Drda, F.E. Harvey, and J. Goeke. 1999. Hydrologic setting of two interdunal valleys in the central Sand Hills of Nebraska. Ground Water 37, no. 6: 924-933.

Hobbins, M.T., J.A. Ramirez, T.C. Brown, and L.H.J.M. Claessens. 2001. The complementary relationship in estimation of regional evapotranspiration: The Complementary
Relationship Areal Evapotranspiration and Advection-Aridity models. Water Resources Research 37, no. 5: 1367-1387.

Mau, D.P., and T.C. Winter. 1997. Estimating ground water recharge from streamflow hydrographs for a small mountain watershed in a temperate humid climate, New Hampshire, USA. Ground Water 35, no. 2: 291-304.

Miller, D.H. 1977. Water at the Surface of the Earth. New York: Academic Press.

Morton, F.I., F. Ricard, and F. Fogarasi. 1985. Operational estimates of areal evapotranspiration and lake evaporation: Program WREVAP. National Hydrologic Research Institute Paper no. 24.

Nagel, H.G., and M.S. Dart. 1980. Platte River evapotranspiration: A historical perspective in central Nebraska. Transactions of the Nebraska Academy of Sciences VIII, 55-76.

Nathan, R.J., and T.A. McMahon. 1990. Evaluation of automated techniques for base flow and recession analyses. Water Resources Research 26, no. 7: 1465-1473.

Rantz, S.E. 1968. A suggested method for estimating evapotranspiration by native phreatophytes. Geological Survey Professional Paper 600-D: D10-D12.

Rundquist, D.C., A.J. Peters, L. Di, D.A. Rodekohr, R.L. Ehrman, and G. Murray. 1991. Statewide groundwater-vulnerability assessment in Nebraska using the DRASTIC/GIS model. Geocarto International 2, 51-58.

Rutledge, A.T., and C.C. Daniel III. 1994. Testing an automated method to estimate ground water recharge from streamflow records. Ground Water, 32, no. 2: 180-189.

Scanlon, B.R., R.W. Healy, and P.G. Cook. 2002. Choosing the appropriate techniques for quantifying groundwater recharge. Hydrogeology Journal 10, 18-39.

Szilagyi, J., F.E. Harvey, and J.F. Ayers. 2003. Regional estimation of base recharge to ground water using water balance and a base-flow index. Ground Water 41, no. 4: 504-513.

U.S. Geological Survey. 1990. Land use and land cover digital data from 1:250,000- and 1:100,000-scale maps. U. S. Geological Survey Data User's Guide No. 4, Reston, Virginia.

U.S. Geological Survey. 2003. Estimated mean annual natural ground-water recharge in the conterminous United States, http://water.usgs.gov/lookup/getspatial?rech48grd>. 